\title{
DEVELOPMENT OF SOCIAL AND PROFESSIONAL MOBILITY OF STUDENTS IN THE PROCESS OF PROFESSIONAL TRAINING
}

\begin{abstract}
Tetyana Babenko ${ }^{1}$
${ }^{I}$ Candidate of Pedagogical Sciences, Docent of Pedagogy and education management department Volodymyr VynnychenkoCentral Ukrainian State Pedagogical University, Kropyvnytskyi, Ukraine, e-mail: babenkot80@gmail.com, ORCID: https://orcid.org//0000-0001-5085-2779
\end{abstract}

\begin{abstract}
Modern university graduates must be prepared for the changing tendencies in the labor market in order to be successful. The article gives an interpretation of the concepts of «social and professional mobility of students», "development of social and professional mobility». Science and technologies develop so rapidly that qualification received after graduating from a higher education establishment is not a guarantee of employment in this field. The article describes abilities and personal qualities (initiative, creativity, social and professional activity, ability for risk, selforganization, independence, volitional self-control, determination, self-confidence, openness to something new) which create the student's social and professional mobility. Modern challenges require the search for new effective educational technologies. That's why much attention is paid to rethinking the organization and content of the educational process of higher school on the basis of innovative technologies. Project activities let students to form and develop skills which are necessary for the development of social and professional mobility including: identifying the problem that must be solved; setting the goals and planning the main kinds of activities; reflections; searching for information; communication and interaction; practical application of knowledge in typical and atypical situations; presentation of the results of their activities. It is determined that the participation of students in social projects, on the one hand, is a condition for the development of their social and professional mobility, and on the other hand, is an indicator of its maturity, understanding that everyone is responsible for their city, state, people and it is impossible to build the life beyond the society. There are the examples of social projects in the article.
\end{abstract}

Keywords: social and professional mobility, student, professional training, educational environment, project, project activity, social project.

JEL Classification: JEL I0; I20

Formulas: 0; fig.: 0;tabl.:0; bibl.: 13

Introduction. The current stage of development of society is characterized by dynamic and intense changes covering all spheres of human life. Science and technologies develop so rapidly that qualification received after graduating from a higher education establishment is not a guarantee of employment in this field. Modern university graduates must be prepared for the changing tendencies in the labor market in order to be successful. It means that they must react to changes adequately and effectively, master new professions, new horizons within the existing profession, be active, be able to adapt to new conditions quickly and effectively.

Responding to the demands of the time, higher school should train a new generation of professionals who are interested in their permanent education and development, able to adapt to changing conditions and content of professional activities, to build their careers, to expand their professional opportunities mastering new spheres of professional activity.

Modern challenges require the search for new effective educational technologies. That's why much attention is paid to rethinking the organization and content of the educational process of higher school on the basis of innovative technologies. One of 
the conditions for achieving the goal of modern vocational education - training a competitive, creative, socially and professionally mobile specialist - is to involve students in project activities.

Literature review. The problem of mobility is studied by representatives of different sciences. At the philosophical level, social and professional mobility was studied by M. Weber, B. Gershunsky, I. Vasylenko, I. Frolov, M. Scheler and others. At the sociological level, the problems of population mobility were studied by D. Goldthorpe, L. Liesokhina, R. Erickson, A. Mudryk, and P. Sorokin. Psychological aspects of social and professional mobility were studied by L. Goryunova, E. Zeyer, A. Markov, A. Maslow, N. Pryazhnikov, K. Rogers, and T. Titarenko. Research about development and formation of mobility of individuality at the pedagogical level were made by L. Amirova, L. Goryunova, L. Mitina, Yu. Klymenko, R. Prima, Ye. Rapatsevych, Yu. Sachuk, L. Sushchentseva, O. Sharov and others.

The works of A. Vdovychenko, V. Guzeev, S. Izbash, O. Kobernyk, N. Matyash, O. Piekhota, O. Pometun, Ye. Polat, V. Slobodchenkov, S. Sysoeva, L. Khomenko I. Shendryk and other scientists are devoted to the research of theoretical bases of project activity.

Aims. To analyze the content and possibilities of project activities in the development of social and professional mobility of students.

Methods. The following methods are used in the article:theoretical (analysis, synthesis, classification, comparison, generalization, systematization) for the study of pedagogical literature and clarification of the essence of social and professional mobility of students and the content of project activities; empirical (observations, conversations, expert assessments) to determine the abilities and qualities that form the social and professional mobility of the student.

Discussion. It should be noted that in the modern scientific literature there is no common definition of social and professional mobility. Scientists consider the issue of social and professional mobility very broadly, from the standpoint of self-realization of personality in modern conditions to a basic competence of modern people, as a personal quality and as an indicator of the quality of education. The pedagogical conditions for the formation of professional mobility of future professionals are determined nowadays, the problems of the development of academic mobility of students are studied etc.

The concept of «mobility» has been actively studied recently, only in the second half of the XX century, but it was introduced into scientific world almost a hundred years earlier. P. Sorokin presented the concept of «social mobility», meaning the social movement not only of individuals, groups, but also social objects (values), everything that was created or modified in the process of human activity. To explain the movement in the parameters of social space, the author used the terms «horizontal social mobility» and «vertical social mobility». P. Sorokin associated the first concept with a change in the social status of people, with the career growth of a specialist, and the second one was considered as one that realized at the same status level. Horizontal social mobility involves the transition of an individual from one social group to another located at the same level of social stratification [12]. 
At the present stage, social mobility is no longer related to social status, but characterizes the way of social functioning of human being.

The analysis of researches of essence of social and professional mobility $[1 ; 2 ; 4$; $5 ; 6 ; 7 ; 8 ; 11 ; 13]$ and our research give us the possibility to determine that the components of social and professional mobility of the specialist are the ability to operate effectively in a changing professional environment, to navigate in a changing information environment, to monitor and to assess the environment, to react according to the situation and the goals activity, to adapt to changing conditions and to influence of the surrounding reality, the ability to continuous self-improvement. Among the personal qualities and features that form the ability and readiness for social and professional mobility are: initiative, creativity, social and professional activity, risktaking, self-organization, independence, volitional self-control, determination, selfconfidence, openness to something new.

Personal qualities and abilities that help a person to move from one level of professional activity to another one are not innate, so it becomes possible to form them with educational instruments.

The development of professional and social and professional mobility, is primarily the formation of competitiveness of graduates in the labor market after comprehensive training, combines narrow professionalism on the one hand and universal skills on the other hand [13].

Personality develops in activity. Therefore, involvement in project activities is aimed at stimulating students' interest in different problems and solving these problems through activities. We consider the development of social and professional mobility as a specially designed and projected process of consistent change of personality that includes menthal processes, social and personally active components, which are the elements of personal innovations (personality traits, value-semantic constructs, personal worldview). These innovations determine behavior.

In our opinion, project activity is an effective tool for the development of social and professional mobility of students. Designing acts as a creative, innovative activity because it is always aimed at creating an objectively and subjectively new product [4]. The main task of the project activity is not only the acquisition of knowledge, but also the opportunity to navigate in social, economic, informational events and phenomena, as well as to gain experience of life in our society.

The realities of nowadays require new social experience to form socially active leaders, responsible and proactive professionals. Project activities can be an environment in which students work in various fields, such as organizational, social, scientific, charitable, explanatory, informational spheres. Project activities play important part in formation of personal qualities necessary for self-affirmation and development of volitional skills in interaction with society.

We have to focus on the principles of work at project, their implementation help to effective development of social and professional mobility and to: activity in defining the task and its development; the practical nature of the project, its relevance, feasibility, students' interest in their work, the combination of theory and practice, knowledge and skills; ability to implement the project, independence, creativity, 
teamwork. The variety of goals and objectives of social projects lets us to distinguish cognitive, educational, socializing and developmental functions. Cognitive function helps to increase motivation to acquire new knowledge, develops skills to produce, argue and prove their ideas. The developmental function involves the development of creative and research abilities, the formation of communicative skills, the development of critical thinking, skills of analysis and reflection. The educational function provides awareness of one's own actions regarding self-discipline and responsibility, promotes the formation of universal values and the formation of an active life position. The socializing function involves the development of communication skills in society, independent view of events and phenomena, understanding their capabilities their own role during working in a team.

Project activities let students to form and develop skills which are necessary for the development of social and professional mobility including: identifying the problem that must be solved; the goal setting and planning the main kinds of activities; reflections; searching for information; communication and interaction; practical application of knowledge in typical and atypical situations; presentation of the results of their activities.

Focus on self-development, self-actualization, self-discovery that allow a person to become an active subject of life and professional self-realization is in demand today at the level of personal and social goals. We agree with researchers in the field of modern pedagogy and psychology that without the manifestation of man himself, without his self-expression there is no and cannot be a person. They emphasize the dependence of the life of each of us on self-discovery, on the ways we choose to do so. This is especially important when it comes to teachers and future teachers. After all, it is these people who carry patterns of behavior, self-expression to the younger generation. From them children will perceive possible models of self-expression, selfpresentation. Therefore, a person engaged in pedagogical activities and interacts with the younger generation, should bring them the best examples of self-expression, «correct» ways and methods of self-expression, demonstrating a high level of culture of self-expression.

The formation of these competencies largely depends on the available opportunities for students to present in the learning process to others what is important, meaningful, valuable, essential for him personally - from the availability of opportunities for self-expression. Therefore, one of the important tasks of teacher training is the development of his activity, which is manifested in the desire to adequately realize their inner world through external manifestations.

In our opinion, social projects have a special place in the development of social and professional mobility of students. A social project is a project that is useful for other people, society. Such community-based activities are important for every society, because they improve its general condition and teach people to focus their efforts not only on their own needs, but on the common wealth.

O. Pometun defines social projects as a set of practical actions for solving specific social problems of the local community. She notes that the participation of young people in such projects helps to develop their emotional and evaluative attitude to 
public life, personal activity, the desire for civic action and effective communication [10]. In the context of our research, the opinion of S. Liesnikova is interesting, she says that project activities are effective elements of social initiative. According to her, a social project is an individual or group activity aimed at positive transformation of the social environment and living conditions of adolescents by methods which are available to them. [8].

Participation of students in social projects, on the one hand, is a condition for the development of their social and professional mobility, and on the other hand, is an indicator of their maturity, understanding that everyone is responsible for their city, state, people and that it is impossible to build a comfortable life beyond the society. Here are examples of social projects, the implementation of which helps to form a free, responsible personality: projects that develop youth activity, develop skills and abilities related to public life («Youth government in the community», «Student Government», «Leadership School»); projects that help to improve social competence («Conducting sociological research», «How to be successful», «Doing good things with your own hands»); volunteer projects «Help for Defenders», «Let's give a family to a homeless animal», «Street Children», «For you, heroes!», «Help for retirees of the local community»; , environmental projects «Let's make the city streets green», «Ecological trail», «How many leaves may be burnt in autumn?», «Disposal of energy - saving light bulbs» («Stop global warming - plant the tree»).

Conclusion. Article gives the interpretation of the concepts «social and professional mobility of students», «development of social and professional mobility». We described the abilities and personal qualities (initiative, creativity, social and professional activity, ability for risks, self-organization, independence, volitional selfcontrol, determination, self-confidence, openness to something new) which form the student's social and professional mobility. We proved that project activity is an important condition for the development of social and professional mobility of students in the process of professional training. It is proved that students' participation in social projects is an indicator of their maturity, understanding that everyone is responsible for the fate of their city, state, people and that it is impossible to build a comfortable life beyond the society. We show examples of social projects.

The prospects for further research in this direction may be realized in the development of criteria and indicators, determining the levels of social and professional mobility of students.

\section{References:}

1. Amirova, L. A., Bagishaev, Z. A. (2004), Professionalno-pedagogicheskaya mobilnost uchitelya kak tselevaya ustanovka vyisshego pedagogicheskogo obrazovaniya. [Professional and Pedagogical Mobility of a Teacher as a Target Setting for Higher Pedagogical Education.], Moscow: Alma mater [in Russian].

2. Entsyklopediia osvity (2008) [Encyclopedia of Education], Kyiv: Yurinkom Inter [in Ukrainian].

3. Dyachenko, M. I. (2004), Psihologicheskiy slovar-spravochnik. [Psychological Dictionary]. Moscow: Harvest [in Russian].

4. Zeer, E. F. (2003), Psihologiya professiy [Occupational Psychology]. Moscow: Akademicheskiy proekt [in Russian]. 5. Igoshev, B. M. (2008), Organizatsionno-pedagogicheskaya sistema podgotovki professionalno mobilnyih spetsialistov v pedagogicheskom universitete [Organizational and Pedagogical System of Training Professionally Mobile Specialists at the Pedagogical University], Moscow: VLADOS [in Russian].

6. Ipatova, E. R. (2012), Formirovanie sotsialno-professionalnoy mobilnosti studentov vuza [The Formation of Social and Professional Mobility of University Students]: avtoreferat ... kandidata pedagogicheskih nauk. Shuya, [in Russian]. 
7. Kalinovskiy, Yu. I. (2001), Razvitie sotsialno-professionalnoy mobilnosti andragoga v kontekste sotsiokulturnoy obrazovatelnoy politiki regiona [The Development of Social and Professional Mobility of Andragog in the Context of the Socio-cultural Educational Policy of the Region]: dissertatsiya ... doktora pedagogicheskih nauk. Sankt-Peterburg [in Russian].

8. Lesnikova, S. G. (2001), Proektnaya deyatelnost kak sredstvo razvitiya sotsialnoy initsiativnosti podrostka v usloviyah detskoy obschestvennoy organizatsii [Project Activities as a Means of Developing a Teenager's Social Initiative in a Children's Public Organization]: Dis. ... kand. ped. nauk: 13.00.01. Moscow [in Russian].

9. Lesohina, L. N. (1998), K obschestvu obrazovannyih lyudey. [To a Society of Educated People]. Sankt-Peterburg [in Russian].

10. Pometun, O. I. (2003), Molod obyraie diiu: Sotsialne proektuvannia - novyi pidkhid do vykhovannia molodi [Youth chooses action: Social design is a new approach to youth education], Kyiv: Departament [in Ukrainian].

11. Prima, R. M. (2009), Formuvannia profesiinoi mobilnosti maibutnoho vchytelia pochatkovykh klasiv: teoriia i praktyka: monohrafiia [Forming the Professional Mobility of the Future Primary Elementary Teacher: Theory and Practice]. Dnipropetrovsk: IMA-PRES [in Ukrainian].

12. Sorokin, P. A. (2009), Sotsialnaya mobilnost [Social Mobility] / per. s angl. M. V. Sokolovoy. Moskva: Academia [in Russian].

13. Chernilevskiy, D. V. (2002), Didakticheskie tehnologii v vyisshey shkole. [The Didactic Technology in High School] Moskva: YuNITI [in Russian]. 